\title{
ノクセラーZTC について(1)
}

\section{[IIR 配合】}

ブチルゴム (IIR)はイソブチレンに少量のイソプレン を共重合させたゴムで，その優れた気体不透過性，耐熱 性, 耐オゾン性を持つことなどから, タイヤのチュー ブ，タイヤ加硫用キュアリングバッグなどに使われてい る.

IIR はジェン系ゴムに比べて不飽和度が低いため加硫 速度が遅く, 加硫系としては強力な加硫用薬剤の添加が 必要である。

硫黄加硫の場合は, 加硫促進剤としてチウラム系加硫 促進剤（ノクセラーTT, TSなど）やジチオカルバミン 酸塩系加硫促進剤(ノクセラーPZ, EZ, TTTEなど)を 一次加硫促進剤とし，これに二次加硫促進剤としてチア ゾール系加硫促進剤(ノクセラー M, DM など)又はスル

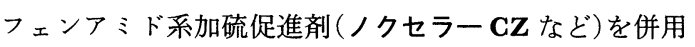
して用いられている(1),2). 一般的にはノクセラーTT/M が使用されている.

今回は, ジチオカルバミン酸塩系加硫促進剤であるノ クセラーZTC (ジベンジルジチオカルバミン酸亜鉛)を 一次加硫促進剤として使用した場合の IIR に対する加 硫性能について紹介する.

表 1 の配合に基づき, 表 2 に示す加硫促進剤を用いた 場合のムーニースコーチ試験及び ODR による加硫試験 結果を表 2 及び図 1 に示す.

ノクセラー ZTC 単独では加硫速度が遅いが，ノクセ
ラー M, CZ 及び NS を併用する事により加硫速度及び 加硫度が向上する．特に，ノクセラー CZ 及び NS は加 工温度ではノクセラー ZTC のスューチ防止剂として働 き, 加硫温度では二次加硫促進として働く．ノクセラー $\mathbf{Z T C}(2.54)$ とノクセラー CZ(2.0) 又は NS(1.0) との併 用(配合 No. 7, 9) では, 従来から使用されているノセラ 一 TT/M と同等のスコーチタイム, 加硫速度及び加硫 度を示す事が認められた。

\section{引用 文 献}

1）合成ゴム誌，No. 86, 1（1981）（日本合成ゴム株式 会社)

2） NOG 技術ノートNo. 243，日ゴム協誌，54，192 (1981)

\section{実験}

1. 配合

表 1

\begin{tabular}{lc}
\hline IIR* & 100 \\
酸化亜鉛 & 5 \\
ステアリン酸 & 1 \\
GPF ブラック & 60 \\
プロセスオイル & 25 \\
硫黄 & 2.0 \\
加硫促進剂 & 表 2 \\
\hline
\end{tabular}

* 不飽和度1.5モル \%

ムーニー粘度 $47 \sim 56\left(\mathrm{ML}_{1+8}, 125^{\circ} \mathrm{C}\right)$

表 2 ムーニースコーチ及びレオメータ加硫試験

\begin{tabular}{|c|c|c|c|c|c|c|}
\hline \multirow[b]{2}{*}{$\begin{array}{l}\text { 加硫促進剤 } \\
{[1]=0.00417 \text { モ33) }}\end{array}$} & \multicolumn{3}{|c|}{ ムーニースコーチ試験1) } & \multicolumn{3}{|c|}{ レオメータ試験2) } \\
\hline & $V_{\mathrm{m}}$ & {$\left[\begin{array}{c}t_{5} \\
{[\mathrm{~min}}\end{array}\right]$} & {$\left[\begin{array}{c}t_{35} \\
{[\mathrm{~min}}\end{array}\right]$} & $\begin{array}{l}M_{\mathrm{H}\left(30^{\prime}\right.} \\
{[\mathrm{N} \cdot \mathrm{m}]}\end{array}$ & $\begin{array}{l}t_{\mathrm{C}(10)}^{\prime} \\
{[\mathrm{min}]}\end{array}$ & $\begin{array}{l}t_{\mathrm{C}(90)}^{\prime} \\
{[\mathrm{min}]}\end{array}$ \\
\hline 1. $\mathbf{T T}[1](1.00)+\mathbf{M}(0.5)$ & 21 & 13.2 & 17.5 & 2.30 & 4.0 & 18.2 \\
\hline $\begin{array}{l}\text { 2. } \mathbf{Z T C}[1](2.54) \\
\text { 3. } \mathbf{M}(0.5)\end{array}$ & $\begin{array}{c}20 \\
\text { 測定せず }\end{array}$ & 9.5 & 15.1 & $\begin{array}{l}1.69 \\
1.02\end{array}$ & $\begin{array}{l}2.1 \\
5.2\end{array}$ & $\begin{array}{l}21.7 \\
26.7\end{array}$ \\
\hline 4. $\mathbf{Z T C}[1](2.54)+\mathbf{M}(0.5)$ & 23 & 6.7 & 10.1 & 2.12 & 1.7 & 20.3 \\
\hline 5. $\mathbf{Z T C}[1](2.54)+\mathbf{M}(1.0)$ & 23 & 6.1 & 9.2 & 2.12 & 1.3 & 20.3 \\
\hline 6. $\mathbf{Z T C}[1](2.54)+\mathbf{C Z}(1.0)$ & 19 & 11.5 & 15.6 & 2.30 & 3.2 & 18.2 \\
\hline 7. $\mathbf{Z T C}[1](2.54)+\mathbf{C Z}(2.0)$ & 20 & 12.8 & 16.8 & 2.30 & 3.8 & 18.2 \\
\hline 8. $\operatorname{ZTC}[1](2.54)+\mathrm{NS}(0.5)$ & 21 & 11.6 & 15.9 & 2.30 & 3.2 & 18.3 \\
\hline 9. $\mathbf{Z T C}[1](2.54)+\mathbf{N S}(1.0)$ & 20 & 13.1 & 17.2 & 2.30 & 4.0 & 18.2 \\
\hline 10. $\operatorname{ZTC}[1](2.54)+\mathbf{N S}(2.0)$ & 20 & 14.4 & 17.7 & 2.30 & 4.5 & 18.5 \\
\hline
\end{tabular}

1） JIS K 6300に準拠 $\mathrm{ML}_{-1}, 135^{\circ} \mathrm{C}$ 2) モンサント ODR-100, $160^{\circ} \mathrm{C}$

3） $[1]=0.00417$ ルはTT $1.00 \mathrm{phr}$ を基準とした. 

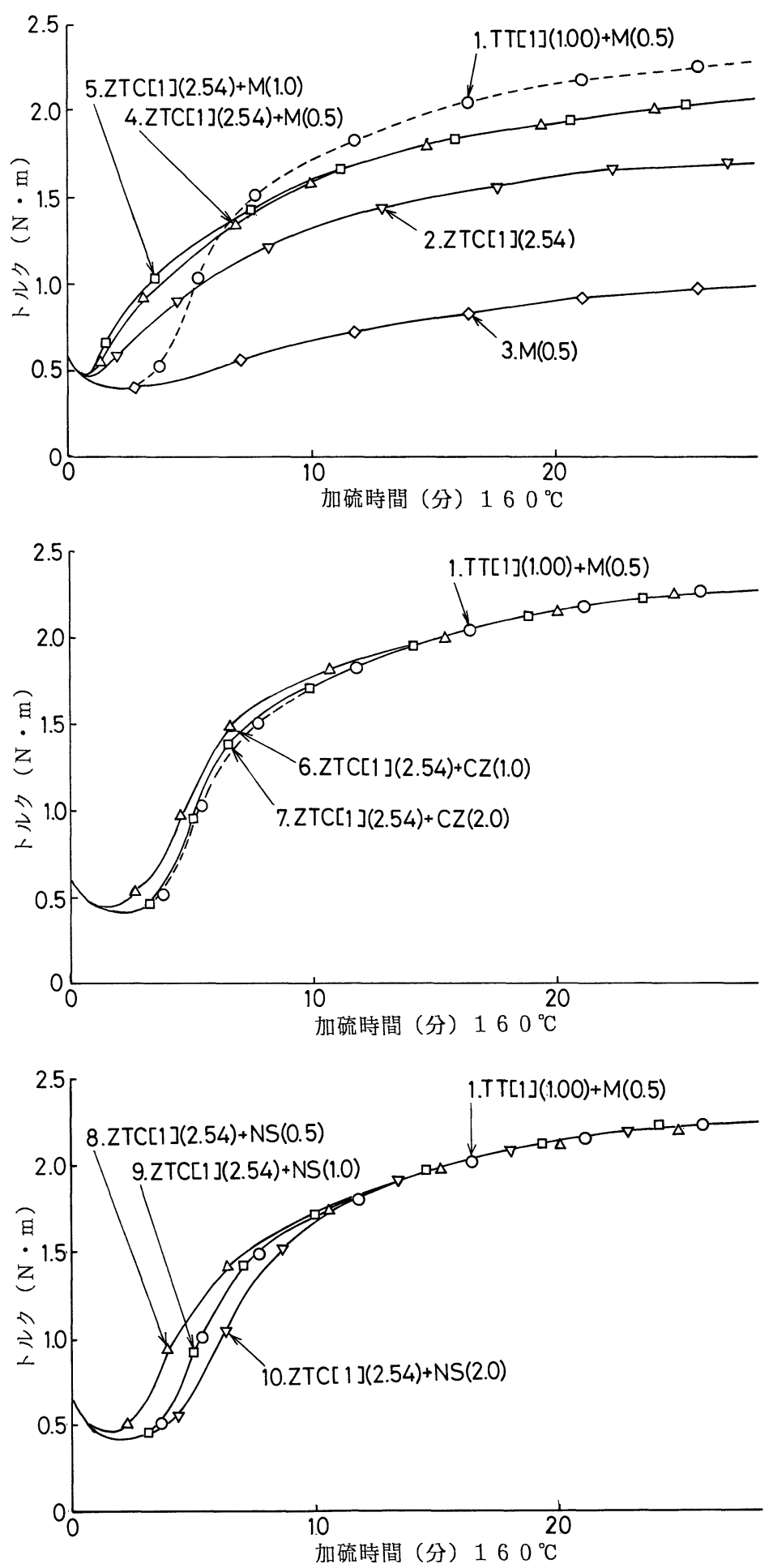

図 1 レオメータ加硫曲線(モンサント ODR-100)

$[1]=0.0047 € ル, \quad(\quad)$ 内 $\mathrm{phr}$

大内新興化学工業株式会社 